Article

\title{
Specific Skill Requirements within Prefabricated Residential Construction: Stakeholders' Perspectives
}

\author{
Funmilayo Ebun Rotimi ${ }^{1, *(\mathbb{D}}$, Firas Majthoub Almughrabi ${ }^{2}$, Don Amila Sajeevan Samarasinghe ${ }^{3}$ \\ and Chathurani Silva 4 (D) \\ 1 Built Environment Engineering, School of Future Environments, Auckland University of Technology, \\ Auckland 1010, New Zealand \\ 2 Auckland International Campus, Otago Polytechnic, Auckland 1010, New Zealand; \\ Firas.Almughrabi@op.ac.nz \\ 3 School of Built Environment, College of Sciences, Massey University, Auckland 0632, New Zealand; \\ D.Samarasinghe@massey.ac.nz \\ 4 Department of Decision Sciences, Faculty of Management Studies \& Commerce, University of Sri \\ Jayewardenepura, Gangodawila, Nugegoda 10250, Sri Lanka; chathurani@sjp.ac.lk \\ * Correspondence: funmi.rotimi@aut.ac.nz
}

Citation: Rotimi, F.E.; Almughrabi, F.M.; Samarasinghe, D.A.S.; Silva, C. Specific Skill Requirements within Prefabricated Residential

Construction: Stakeholders'

Perspectives. Buildings 2022, 12, 43.

https://doi.org/10.3390/

buildings12010043

Academic Editor: Audrius Banaitis

Received: 8 December 2021

Accepted: 28 December 2021

Published: 4 January 2022

Publisher's Note: MDPI stays neutral with regard to jurisdictional claims in published maps and institutional affiliations.

Copyright: (C) 2022 by the authors. Licensee MDPI, Basel, Switzerland. This article is an open access article distributed under the terms and conditions of the Creative Commons Attribution (CC BY) license (https:// creativecommons.org/licenses/by/ $4.0 /)$.

\begin{abstract}
Skill availability is an important component in the uptake of prefabrication and plays a crucial role in housing supply. However, the challenge is that the demand for housing has outgrown the availability of specifically trained workers. This challenge is not unique to New Zealand; many developed countries worldwide are facing similar issues. Therefore, the purpose of this study is to determine relevant skills in the prefabricated residential construction sector in New Zealand (NZ) and suggest improvement measures from the standpoint of industry stakeholders. The study adopted a semi-structured online survey and administered it to multiple construction industry practitioners. The study found the training of the construction workforce as one significant area of focus. In addition, external sourcing of international prefabrication-specific skilled workers could improve the issues of skill shortages in the residential prefabrication sector. Furthermore, the study revealed that the barriers to healthier prefabrication uptake are closely linked to shortages in management, digital architecture and design, and vocational skills related to residential construction. The study has contributed to the current pool of knowledge by identifying skill issues in NZ's prefabricated residential construction sector, classifying the major restraints limiting prefabrication implementation, and determining measures for increasing industry uptake. It is anticipated that this will help construction organizations and the wider industry develop strategic goals and a roadmap for meeting the skill requirements in NZ. Training policies and programmes can be developed with focus on crucial prefabrication skill requirements at governmental level. Curriculum reviews are recommended for uptake by academic and vocational institutions.
\end{abstract}

Keywords: prefabrication; skills; training; vocational

\section{Introduction}

The present era is characterized by rapid technological changes, creativity and innovation. However, the construction industry has not participated to the same extent as other industries and is seen as inefficient [1]. Although some significant and rapid changes have occurred within the construction industry, through the adoption of new and innovative technologies to create a competitive advantage, these are largely incomparable [2]. Seminal literature argues that prefabrication, as a modern technique, could effectively address the residential housing shortages within the construction sector [3,4]. Similarly, research suggests that benefits could be derived by replacing or supplementing traditional on-site construction with the prefabrication method $[5,6]$. These benefits include faster construction time, more energy and economic efficiency, safer manufacturing, and superior quality 
and performance [7-10]. Other benefits include durability, which is critical to sustainable housing delivery. Overall, prefabrication methods have been suggested to address the issue of productivity within the industry $[1,11]$. Productivity stems from improvements in processes which has been a focus of attention in more recent arguments around the concepts of circular economy. Circular economy arguments provide justifications for social and economic advantages [12], environmental benefits [13], and resource-effectiveness [14].

Within the context of this study, prefabrication integrates appropriately with the circular economy concepts. Minunno et al. [13], for example, have shown how prefabrication in terms of reduction, reusability, adaptability, and recyclability of building components, provide environmental advantages. Further, Duncheva and Hairstans [15] describe the reduced need for onsite labour and inherent efficiency gains with the use of prefabrication as corresponding with the sustainability factor in circular economy. Despite these clear alignments, Osobajo et al. [16] suggest that further research investigations are required to demonstrate circularity on prefabrication to support resource use and waste reduction objectives. In terms of affordability and acceptability in housing provision, prefabrication portends benefits. Affordable and acceptable quality housing is considered one of the biggest concerns in NZ [17]. In 2012, about $27 \%$ of NZ children were living in poverty because of housing costs. The percentage dropped to $24 \%$ in the following year but was still considered to be high, affecting 260,000 children [18]. Poor health is another problem that stems from unaffordable and low-quality housing. Dale et al. [18] reported that about 300,000 homes in the country were uninsulated and extremely cold, and families could not afford heating costs. Therefore, families had to use cheap and unhealthy heating options (non-flued gas heating), a major cause of asthma. In 2017, Auckland had a deficit of 45,000 units, $18 \%$ higher than the figure recorded the previous year [19]. By 2018, the housing supply shortage was 100,000 units nationwide, while the figure soared to 130,000 homes in 2019 [20]. These studies highlight the importance of adopting new and innovative methods to resolve the housing shortage issues in NZ.

Despite the financial crisis caused by the COVID-19 pandemic, median house prices for NZ residential properties increased by $28.7 \%$, rising from NZD 637,000 in June 2020 to NZD 820,000 in June 2021 [21]. According to Edmunds [22], NZ has become one of the most expensive countries in terms of housing affordability, with a price-to-income ratio of 6.5. That ratio was just 2.16 in the 1990s [22]. The national home ownership rate of $65 \%$ in 2018 meant that $35 \%$ of NZ households did not own their houses [19]. Only six cities-Hong Kong, Vancouver, Sydney, Melbourne, Los Angeles and Torontotopped Auckland in housing unaffordability. In Hong Kong, where $20 \%$ of citizens live below the poverty line, property prices are still high [23]. From the preceding facts and figures, housing affordability in NZ is a topical issue requiring considerable attention. Studies have suggested prefabrication as a solution with extensive use viable in housing provision, although the integration of prefabrication into operational practice has been patchy $[24,25]$. Studies have shown that the lack of skills is a major contributor to poor uptake of prefabrication in most economies [3,26]. Addressing this issue will increase awareness of the benefits of prefabrication over the conventional methods.

This current study assumes that improvement in the provision of relevant skills and training plans could assist the uptake of prefabrication in residential construction. Therefore, the study aims to determine the skills needed to facilitate the uptake of prefabrication in NZ, from the perception of industry stakeholders. We conclude that the questions that need to be asked to fulfill the research aim are:

RQ1: What are the skills required to facilitate uptake of prefabrication in NZ?

RQ2: What other measures are needed to facilitate uptake of prefabrication in NZ?

\section{Literature Review}

Given environmental concerns and the looming housing crisis resulting from a growth in population, the need to increase the uptake of prefabrication has secured global attention. The word prefabrication has been used interchangeably in the literature. Some 
of the commonly used terminologies are standardization and pre-assembly, off-site construction (OSC), and modern methods of construction (MMC) and off-site manufacturing (OSM) $[26,27]$. For the current research, prefabrication was adopted in the survey and analysis. While a variety of definitions of the word prefabrication have been suggested, this study will use the definition suggested by Burgess et al., [28] who saw it as "practices, systems, and structures which facilitate the construction of buildings and parts of buildings away from their final location. These buildings or parts of buildings are then brought onto the site at the appropriate time and assembled and completed as necessary". Prefabrication includes component-based, panelised, modular and hybrid. The following section will discuss prefabrication from a global perspective [28].

\subsection{Global Perception}

Globally, as an innovative approach, prefabrication is not in extensive use, even though it may be intuitively appealing [25]. In the United States (US), for example, regardless of all the well-known benefits in terms of sustainability and economic efficiency, there are still challenges to the uptake of prefabrication from different industry stakeholders and the market in general. In the US, Razkenari et al. [1] found that the most significant barriers to prefabrication are a lack of contractor experience, inflexibility in allowing design changes and a lack of familiarity with off-site practices and/or knowledge. Razkenari et al. [1] suggested improvement measures such as enhancing design modularization, generating further building information modelling (BIM) to the industry and mitigating the disconnect between supply and demand to attain the correct balance within the prefabrication market. Their study further suggested the Design for Manufacturing and Assembly (DFMA) principle as an innovative technology for wider integration within the prefabrication industry [1]

In the UK, the Planning, BIM \& Construction (PBC) Today [29] website shows that only $7.5 \%$ of newly built houses used prefabricated members, compared to $15 \%$ in Japan and $84 \%$ in Sweden. In an earlier study, Arif et al. [30] had suggested that the high cost of production was the key barrier preventing greater adoption of prefabricated houses. However, the researchers pointed out that the effective use of engineering methodology focusing on reducing the total production cost, such as DFMA, could reduce the probability of cost hikes. Similarly, Lovell and Smith [31] acknowledged that the first barrier on the way to a healthier position for prefabrication construction was its high establishing cost. Their study also addressed negative public perception about prefabricated homes, along with a lack of demand in the market, as potential factors underpinning the resistance to prefabrication. McGinnis [32] highlighted the need for industry to cooperatively provide higher-quality training courses for new employees. Further, McGinnis [32] suggested the development of learning modules that concentrate on concepts relating to prefabrication such as DFMA.

Within the context of Australia, the prefabricated building industry contributes 3-5\% of the AUD 150 billion value of the construction industry. According to its Minister for Industry, Science and Technology [33], that figure could grow by up to $15 \%$ in 2025, generating an extra 20,000 new jobs and adding NZD 30 billion in economic growth. The Australian government dedicated NZD 2 million to establish a collaborative innovation laboratory to help manufacturers to design new prefabricated buildings that are more affordable and create less environmental harm. Prefabricated construction was among the eight visions that Hampson and Brandon [34] identified to increase the construction industry's contribution to the Australian economy by 2020. They aimed to restructure the construction supply chain to remove the non-value activities (anything customers are not willing to pay for) and keep delivering quality products punctually with minimum cost and maximum efficiency. Navaratnam et al. [35] hold the view that, in Australia, prefabricated construction has a decent chance of increasing its market share. However, similar to other countries, there are possible barriers still limiting its potential. These barriers are mostly related to a lack of knowledge about the tools and flexibility of the prefabricated system, and minimal public information about system sustainability. Moreover, the authors 
indicated that academic schools and vocational institutions must be encouraged to add the prefabrication construction science aspects to their official courses. They also specified the importance of transportation facilities and regulations in increasing the acceptance of prefabricated construction among industry partners. Another Australian study noted inadequacies in the existing classification system, the unavailability of OSC-specific skill categorisation and a need to have an off-site-specific construction skill classification. Their study highlighted new skills and roles coming through into OSC. These include BIM engineer, three-dimensional draftsperson, OSC project manager and project coordinator. The study found that these are not identified in the available Australian skill classifications. These, together with some existing skills, need to be part of a new skill classification [36].

The government of Singapore developed some initiatives and interventions to improve the adoption of OSM under their current industry transformation map (ITM). The government mandated the use of OSM for developers interested in acquiring government-owned land to be used for residential housing [37]. Such strategic plans between governments and industry stakeholders could incentivize actors in housebuilding sectors to adopt the use of OSM $[38,39]$. Similarly, in Hong Kong, government policy has made the use of OSM a requirement for public housing projects. Coupled with the provision of funding incentives, the policy has promoted the use of volumetric units in building new public-sector-funded housing [40].

In NZ, about $17 \%$ of commercial and residential construction is built using prefabricated parts [41]. Hunt [42] indicates that an increase of $1 \%$ in construction labour productivity could be worth NZD 139 million in GDP. A healthy uptake of prefabrication in NZ requires a modern understanding of industry concepts and a cooperative approach between the different supply chain stakeholders, with full support from government authorities [43]. A wide range of prefabricated products becomes essential if the industry is to create more modern designs [44]. However, leaving design drawings open for ongoing modifications seems to be an additional constraint that causes extra cost, time and uncertainty, and could lead to a budget explosion [45]. Hence, the ability to confirm the drawings and secure better discipline in the building procedure could ease some of the contractors' anxieties and entice them back to the prefabrication industry [5]. The tiny size of the NZ construction market and the lack of innovation in the sector could be the key reasons limiting the acceptance of the technology. Even though prefabrication has benefited significantly from the cuttingedge technologies of computer-aided design and computer-aided manufacturing (CAD, CAM), its uptake in NZ is still below target [28]. Examining the whole picture of the NZ construction industry requires a deeper understanding of a complicated industry situation. The immediate housing crisis requires more dwellings to be built, but, in the long-term, the limitation of natural resources, an ever-rising population and environmental threats could push the whole country towards a prefabricated future. Kennerly [46] explains that efforts were made to explore whether the implementation of prefabrication could provide more affordable houses for New Zealanders, and whether the industry will face the same obstacles in terms of skills availability. Therefore, the current study attempts to address the potential skills shortages in the NZ prefabrication industry that could affect a desirable transformation of the residential construction sector. This study assumes that identifying the right skills could contribute to an increased general uptake of prefabrication.

Some notable studies in developing countries have highlighted growing interest in efforts to create awareness of the significance of prefabrication adoption within their construction industries. These developing countries include China [47], India [48], Nigeria [3] and Cambodia [26]. All of these studies have equally identified a lack of skills as a major barrier to the full adoption of prefabrication. For example, the Durdyev and Ismail [26] study in Cambodia found the most significant barrier was the lack of a skilled workforce within OSM suppliers. Based on these findings, it can be suggested that construction industry decision-makers must channel available resources and invest their efforts in improving prefabrication skills and expertise. In China, Mao et al. [47] found the most significant obstacle inhibiting the use of prefabrication was a lack of government regulations and 
incentives, followed by the high initial cost and a dependence on traditional construction methods. In Nigeria, barriers included limited cost design flexibility, a shortage of local skills and knowledge, a lack of government policies and regulations, a negative image of the industry, client resistance, infrastructure and equipment need, and logistics and supply chain issues [3].

Although this study's focus is not the barriers affecting the adoption of prefabrication, it is important to mention that the shortage of relevant skills was consistently identified as a limiting factor; therefore, this study shares the view of Durdyev and Ismail [26] that OSM uptake levels will continue to improve if the barriers to its adoption are overcome.

\subsection{Skills Necessary for High Uptake of Prefabrication}

As alluded to in the previous section, several studies have indicated the need to improve skills to increase the uptake of prefabrication in the residential construction sector [25,28]. Further, Armstrong [49] indicated that $44 \%$ of global construction firms failed to secure enough craft labour, and $45 \%$ of these organizations lacked qualified employees. Notably, 69\% of the construction organizations in Armstrong's study admitted that more than $5 \%$ of their workforce was hired through external sources. Building more prefabricated residentials require a higher percentage of hybrid skills workers or blended talents, and capabilities in both construction and manufacturing packages [50].

An earlier study by Blismas and Wakefield [25] revealed that skills shortages and inadequate OSM knowledge are generally the most significant issues facing OSM in Australia. More than a decade after, Masood et al. [38] and Sooriyamudalige et al. [51] also pointed out that the skill shortage problem still exists. Their studies highlighted skill shortages in modular construction and penalised offsite products.

Similarly, Bell [52] identified factors such as the lack of skilled workers ready to participate in the prefabrication industry, a situation which can stem from poor vocational education, unclear wage mechanisms and inadequate skills for solving a combination of onsite and off-site issues. These are recognised as critical challenges that hinder prefabrication companies' performance in NZ. Along the same argument, Chen and Samarasinghe [53] acknowledge that the skills needed to operate new technology within the industry are absent, making contractors uninterested in the broader implementation of the prefabricated construction. Therefore, this study aims to discover the possible skills shortage in the NZ prefabrication industry, to improve the whole experience of this technology.

More recently, Sahin et al. [54] found that skills and knowledge availability are pivotal to OSC implementation. The skills of industry practitioners on the subject have to be of a higher standard as OSC is extremely different from traditional construction. Various relevant skills for better uptake of prefabrication have been identified in extant literature. Ginigaddar et al. [36] classified these skills into professional and vocational categories. Professional skills critical for off-site construction are knowledge in DFMA, BIM, digital design, commercial estimating, OSM and logistics production engineering, process efficiency and multi-skills [55-58]. Vocational skills include logistics and sub-assembly operations [59,60], multi-skills through on and offsite job experience $[55,57]$. Others are fundamental manufacturing practices such as quality control and assurance, lean philosophy and total quality management $[59,61]$. Blismas and Wakefield [25] confirmed that skills act as both the driver and barrier for OSC implementation, especially in Australia due to the increased skill shortage of construction tradesmen. Therefore, our current study seeks to identify key skills relevant to prefabrication uptake within the NZ construction industry. The review of extant literature shows a gap of knowledge regarding skills requirement for residential prefabrication in NZ. Therein lies the motivation for this study.

\section{Research Methodology}

To address the identified knowledge gap in this study, a semi-structured questionnaire survey was designed to establish the skills needed to facilitate the uptake of prefabrication in NZ. The survey was administered to multiple industry stakeholders, such as manufac- 
turers, suppliers, engineers, designers, contractors and subcontractors. This captures their viewpoints on skills requirements within the NZ construction industry. A questionnaire survey was chosen over the other data collection methods because it could help collect information from these clusters regarding their attitudes, characteristics, and expectations of prefabrication [62].

The semi-structured questionnaire was administered online through Qualtrics because it offers an efficient way of gathering a considerable amount of data with minimum human efforts and mistakes [63]. Qualtrics allows researchers to use multiple question options and different distribution channels, enhancing the survey design and accuracy [64]. The questionnaire was designed to contain five sections. Four of the sections had close-ended questions, and the last section was open-ended, where responses were not limited or controlled. For this study, four sections covering: (a) general information, (b) skills shortages in residential prefabricated sector, (c) possible measures to increase the prefabrication uptake in the New Zealand housing sector, and (d) open-ended questions. The response to sections (b) and (c) was restricted to the pre-designed responses provided, which were predominantly based on a Likert scale of 1 to 5, where 1 represented "strongly disagree" and 5 "strongly agree". There were 49 responses to the survey.

Before administering the questionnaire to the participants, a pilot study was conducted to determine whether crucial aspects of the study had been covered. According to Van Teijlingen et al. [65], this preliminary study helps to ascertain probable outcomes and study success possibilities. A total of 14 responses were obtained from the pilot survey [66], more than the 12 suggested by Moore et al. [67]. The questionnaire was modified based on the responses and comments received from the pilot survey. A large proportion of the changes dealt with rewording or rephrasing the questions. Ethical approval was sought from the Auckland University of Technology Ethical Committee (AUTEC). This considers all ethical issues at all stages of the research design and execution process in line with Mertens' [68] suggestions. Ethics approval was granted by the Human Ethics Committee on 16 December 2020 (AUTEC Reference Number 20/396).

\section{Data Analysis Method}

The methods of data analysis for this study included descriptive statistics, mean comparisons, and thematic analysis. Statistical tools (using SPSS) were used for the analysis of the close-ended questions, to explore the data, and present them in tables and graphs to show the data distribution patterns that emerged after applying the statistical tests [69]. In the preliminary analysis, the composition of the sample based on age, experience in the NZ construction industry, highest level of education, business category and location were described using frequency tables including percentages. Graphical representation of means using bar charts and one sample $t$ test were the statistical tools applied in the main part of data analysis. Means of the variables were visualized on horizontal bar charts to compare between the four skill issues, and five potential measures identified in the study. One-sample $t$ test was applied separately for each variable to test whether the average agreement of the respondents was higher than the mid-point of the 5-point Likert scale, which represented the 'neutral' opinion in the survey. Accordingly, the alternative hypothesis tested in the study was mean score $(\mu)>3$, which implied that the selected variable had been identified as a significant skill issue, or a potential measure.

Thematic analyses were performed on the open-ended questions using NVivo for coding and analysis. The response to the open-ended questions were in textual format. NVivo allows the researcher to explore textual data to see patterns [70]. NVivo software was chosen because of the nature of the data and burden associated with manual coding. That way, the researcher was able to focus on finding underlying themes, interpretation and theory. In addition, retrieval is easier with the use of NVivo [70]. Initially, the transcripts were systematically analysed to generate meaningful segments of data that addressed the research objectives. Secondly, this data set was coded and organized into meaningful groups, which formed the basis of repeated themes. Coding was both inductive [71] and 
deductive [55]; thus, the study could employ the best advantages of a blended approach [72] Thus, the coding process focused on searching for concepts, words, ideas and patterns that described and reflected skills relevant to the uptake of prefabrication. Both similarities and differences were deemed to be areas of interest. Third, the identified themes were organized into global themes [73].

\section{Results and Analysis}

\subsection{Sample Characteristics}

Table 1 describes the survey participants' age, experience in the NZ construction industry, and their highest level of education. According to these results, approximately $80 \%$ of survey participants were in the mid-ages (30-60 years) and more than $85 \%$ were older than 30 years. Overall, $74.5 \%$ participants had more than five years of experience in the construction industry. Around $92 \%$ of survey respondents had a qualification at diploma level or above. This information on participant age, experience and education ensured that the opinions gathered in the survey of this study is satisfactorily reliable and can be used to make valid conclusions on New Zealand construction industry. These attributes show participants have the required competence to add remarkable value to this study.

Table 1. Profile of the survey participants.

\begin{tabular}{|c|c|c|c|c|c|}
\hline Age (Years) & $\begin{array}{l}\text { Frequency } \\
\text { (Percent) }\end{array}$ & $\begin{array}{l}\text { NZ Construction } \\
\text { Experience }\end{array}$ & $\begin{array}{l}\text { Frequency } \\
\text { (Percent) }\end{array}$ & $\begin{array}{l}\text { Highest Level of } \\
\text { Education }\end{array}$ & $\begin{array}{c}\text { Frequency } \\
\text { (Percent) }\end{array}$ \\
\hline $20-30$ & $\begin{array}{c}7 \\
(14.3 \%)\end{array}$ & Less than 5 years & $\begin{array}{c}13 \\
(26.5 \%)\end{array}$ & Certificate & $\begin{array}{c}3 \\
(6.1 \%)\end{array}$ \\
\hline $31-40$ & $\begin{array}{c}20 \\
(40.8 \%)\end{array}$ & $6-10$ years & $\begin{array}{c}13 \\
(26.5 \%)\end{array}$ & Degree & $\begin{array}{c}18 \\
(36.7 \%)\end{array}$ \\
\hline $41-50$ & $\begin{array}{c}10 \\
(20.4 \%)\end{array}$ & $11-15$ years & $\begin{array}{c}9 \\
(18.4 \%)\end{array}$ & Diploma & $\begin{array}{c}7 \\
(14.3 \%)\end{array}$ \\
\hline $51-60$ & $\begin{array}{c}9 \\
(18.4 \%\end{array}$ & 16-20 years & $\begin{array}{c}5 \\
(10.2 \%)\end{array}$ & Postgraduate & $\begin{array}{c}20 \\
(40.8 \%)\end{array}$ \\
\hline 60 or above & $\begin{array}{c}3 \\
(6.1 \%)\end{array}$ & $21-25$ years & $\begin{array}{c}3 \\
(6.1 \%)\end{array}$ & Other & $\begin{array}{c}1 \\
(2.0 \%)\end{array}$ \\
\hline \multirow[t]{2}{*}{ Total } & $\begin{array}{c}49 \\
(100.0 \%)\end{array}$ & Over 25 years & $\begin{array}{c}6 \\
(12.2 \%)\end{array}$ & Total & $\begin{array}{c}49 \\
(100.0 \%)\end{array}$ \\
\hline & & Total & $\begin{array}{c}49 \\
(100.0 \%)\end{array}$ & & \\
\hline
\end{tabular}

The configuration of the sample based on type of business and location is presented in Table 2. As indicated by these data, the sample of this study is well representative, and it captures various roles in the construction industry. As far as the location is concerned, more than $75 \%$ of participants were based in Auckland. This composition is justifiable considering that prefabricated construction is more common in Auckland than in other regions of NZ. Overall, the sample of this study is sufficiently large and representative for conducting a descriptive statistical analysis and mean comparison. 
Table 2. Business category and participants' location.

\begin{tabular}{cccc}
\hline Age (Years) & Frequency (Percent) & Location & $\begin{array}{c}\text { Frequency } \\
\text { (Percent) }\end{array}$ \\
\hline Contractor & $\begin{array}{c}12 \\
(24.5 \%)\end{array}$ & Auckland & $\begin{array}{c}37 \\
(75.5 \%)\end{array}$ \\
\hline Architect & 3 & Wellington & 37 \\
& $(6.1 \%)$ & Christchurch & $(75.5 \%)$ \\
\hline Engineer & 17 & Hamilton & 3 \\
Manufacturer & $(34.7 \%)$ & Others & $(6.1 \%)$ \\
\hline Consultants & 6 & & $(2.0 \%)$ \\
\hline Sub-contractor & $(12.2 \%)$ & & $(8.2 \%)$ \\
\hline Total & $(16.3 \%)$ & Total & 49 \\
\hline & 3 & & $(100.0 \%)$ \\
\hline
\end{tabular}

\subsection{Skill Issues in Prefabrication}

This study considered four possible issues in NZ's prefabricated construction industry. These include (1) difficulty in recruiting skilled workers, (2) not hiring laborers with multiple skills, (3) insufficient training placements available in the industry, and (4) not borrowing overseas labour. Figure 1 shows the average scores calculated based on the experienced practitioners' viewpoints. According to these results, difficulty in recruiting skilled workers and not hiring multi-skilled labour are the major issues. In addition, onesample $t$ test was performed to test whether the construction professionals agreed that each of these issues were actually skill issues in the prefabrication construction industry. To test this, the average of each issue was compared with the mid-point of 5-point Likert scale which represented the "neutral" opinion in the survey. Table 3 presents these results, and they confirm that difficulty in recruiting skilled workers, not hiring multi-skilled labour and not borrowing overseas labour are all significant issues in the prefabricated construction industry. However, insufficient training placements available in the industry is not a prominent issue according to this analysis.

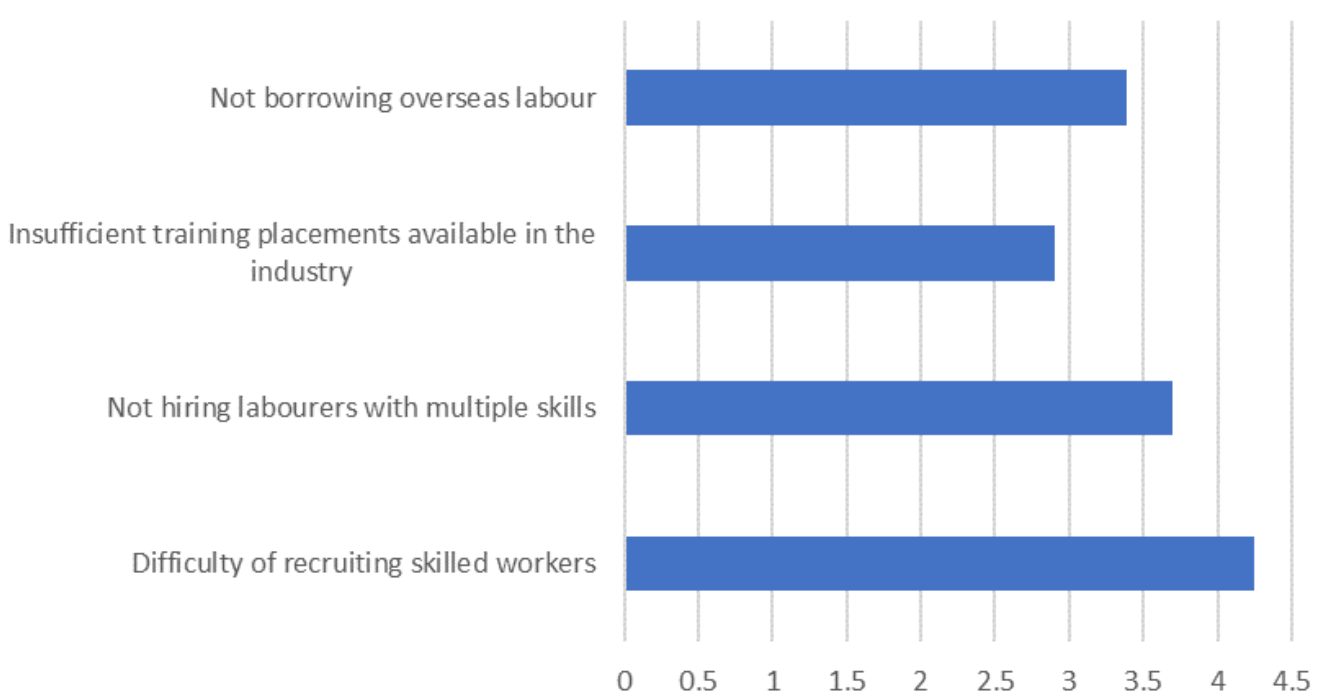

Figure 1. Skill issues in the prefabrication construction industry. 
Table 3. Mean comparison of skill issues in the prefabricated construction industry.

\begin{tabular}{ccccc}
\hline Skill Issue & Mean & Std Dev & $\begin{array}{c}\boldsymbol{t} \text { Test } \\
\boldsymbol{p} \text { Value }\end{array}$ & $\begin{array}{c}\text { Result } \\
\left(\boldsymbol{H}_{\mathbf{1}}: \boldsymbol{\mu} \boldsymbol{\text { 3) }}\right)\end{array}$ \\
\hline Difficulty of recruiting skilled workers & 4.24 & 0.925 & 0.000 & Confirmed \\
Not hiring laborers with multiple skills & 3.69 & 0.895 & 0.000 & Confirmed \\
Insufficient training placements available & 2.90 & 1.295 & 0.292 & Not confirmed \\
in the industry & 3.39 & 1.239 & 0.016 & Confirmed \\
Not borrowing overseas labour & & &
\end{tabular}

\subsection{Measures to Increase Prefabrication Uptake in the NZ Housing Supply Chain}

This study investigated five possible measures to increase the prefabrication uptake in the NZ housing supply chain. These are: (1) extensive implementation of BIM and life cycle assessment (LCA), (2) sufficient training placements, (3) a high level of collaboration between the different industry stakeholders, (4) taking prefabrication as the future of architecture, and (5) using technologies to provide better upfront planning in the residential prefabrication sector. The graph of averages given in Figure 2 shows that stakeholder collaborations and using technology for upfront planning were the most highlighted by the industry experts as possible measures to increase the prefabrication uptake in NZ housing supply chains. As implied by these results, technology-enabled collaborative planning with supply chain partners would be extremely useful for NZ construction companies to increase the adoption of prefabrication in the housing sector.

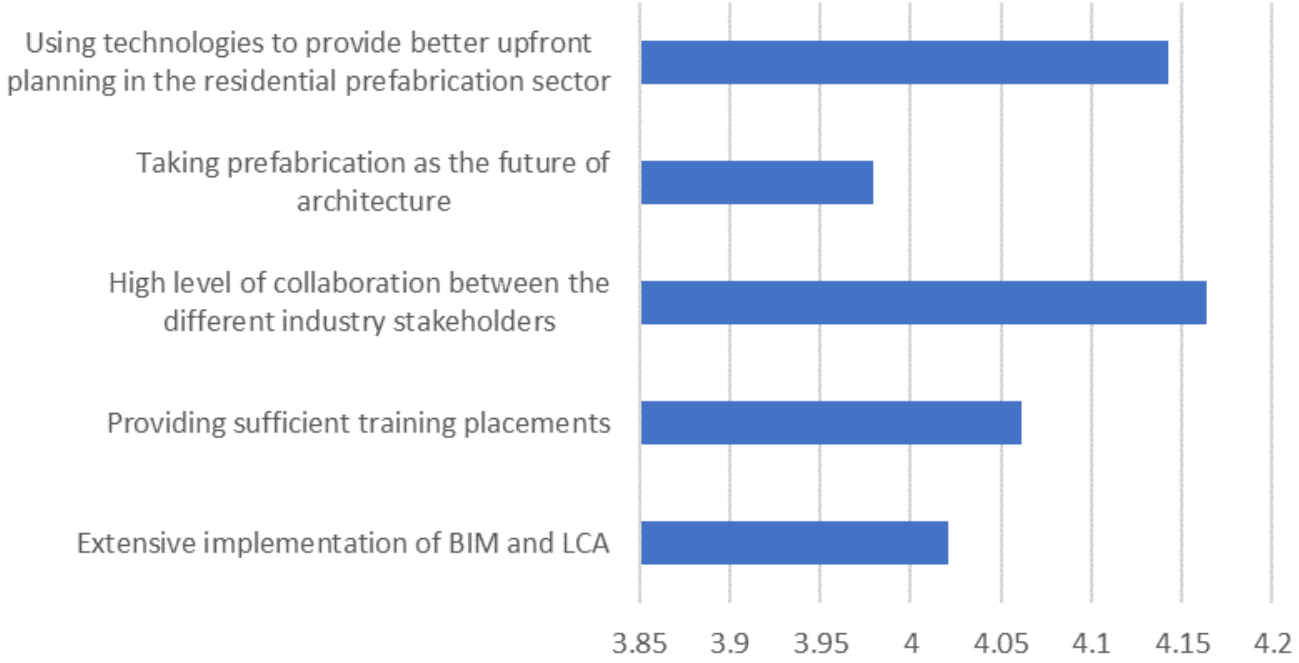

Figure 2. Possible measures to increase prefabrication uptake.

Table 4 presents the results of one-sample $t$ tests performed to check whether the identified factors were significant measures to increase prefabrication uptake in the NZ housing supply chain. Based on the feedback received from experienced construction professionals, the average of each of five measures was compared with the mid-point of 5-point Likert scale which represented the "neutral" opinion in the survey. The statistical results reveal that each measure will significantly help firms to increase prefabrication uptake in the NZ housing supply chain. 
Table 4. Mean comparison of possible measures to increase prefabrication uptake.

\begin{tabular}{|c|c|c|c|c|}
\hline Possible Measures & Mean & Std Dev & $\begin{array}{c}t \text { Test } \\
p \text { Value }\end{array}$ & $\begin{array}{c}\text { Result } \\
\left(H_{1}: \mu>3\right)\end{array}$ \\
\hline Extensive implementation of BIM and LCA & 4.02 & 1.031 & 0.000 & Confirmed \\
\hline Providing sufficient training placements & 4.06 & 0.966 & 0.000 & Confirmed \\
\hline $\begin{array}{c}\text { High level of collaboration between the different } \\
\text { industry stakeholders }\end{array}$ & 4.16 & 0.986 & 0.000 & Confirmed \\
\hline Taking prefabrication as the future of architecture & 3.98 & 0.968 & 0.000 & Confirmed \\
\hline $\begin{array}{l}\text { Using technologies to provide better upfront } \\
\text { planning in the residential prefabrication sector }\end{array}$ & 4.14 & 1.041 & 0.000 & Confirmed \\
\hline
\end{tabular}

\subsection{Open-Ended Questions}

The last part of the questionnaire consisted of four open-ended questions designed to give research participants the opportunity to provide supplementary information about barriers to implementing prefabrication, critical skills essential to improve prefabrication, essential measures that could increase prefabrication and ways to improve skill shortage in prefabrication in the NZ residential building sector. This part of the questionnaire used a qualitative analytical method (thematic analysis) described in the methodology section. It was considered that qualitative analysis would usefully supplement and extend the quantitative measures. For this study, only three questions from the open-ended questions will be reported. The open-ended data were classified into themes and sub-themes through an inductive approach by reviewing the responses and identifying repetitions and transitions. The responses to the open-ended questions are presented in the following sections. For ease of presentation, transcripts of the responses relating to each theme are collated in tabular format. The tables show the theme, subthemes, illustrative responses and tally (frequency counts).

\subsubsection{Critical Skills Essential to Improving Prefabrication}

The construction industry is significantly influenced by the skills and abilities available to execute its projects successfully. Skills required for prefabrication construction are unique compared to on-site production. Therefore, this question is designed to understand from industry stakeholders the vital skills they believe will be essential for prefabrication construction. The question required participants to identify critical skills needed to improve the performance of prefabrication within the industry. Seventy-three percent (36) of the total research participants (49) responded to this part of the questionnaire. After careful observation of the responses, eight cogent themes emerged from their responses (see Table 5). The themes include architecture and design, digital, education, experience, management, practical and vocational skills, research and development, and training. Within these major themes, there were five sub-themes under management skills. Management skills was the most identified theme with one out of every two participants (18 out of 36) indicating this. It is obvious from the analysis that digital skill was also a prominent theme (14 out of 36), followed by practical and vocational skills, and architecture and design skills (8 each). Five participants identified experience and education. 
Table 5. Critical skills essential to improving the prefabrication.

\begin{tabular}{|c|c|c|c|}
\hline Themes & Sub-Themes & Illustrative Responses & Tally \\
\hline $\begin{array}{l}\text { Architecture and } \\
\text { design skills }\end{array}$ & & $\begin{array}{c}\text { Design } \\
\text { Design } \\
\text { Designing skills } \\
\text { Designing skills } \\
\text { Knowledge base within architecture profession } \\
\text { Experience in the design and installation } \\
\text { Architectural skills }\end{array}$ & 8 \\
\hline Digital skills & & $\begin{array}{c}\text { Digital skills } \\
\text { Digital skills } \\
\text { DFMA and BIM/IT skills } \\
\text { Familiarity with technology } \\
\text { Building technology knowledge, CAD and automation } \\
\text { Technical skills } \\
\text { Digital skills } \\
\text { Skills in the use of digital technologies, e.g., DFMA, BIM, Skills in } \\
\text { automation } \\
\text { Use of BIM } \\
\text { Digital manufacturing skills } \\
\text { Digital skills } \\
\text { BIM }\end{array}$ & 14 \\
\hline Education & & $\begin{array}{c}\text { Education } \\
\text { NZ Standards knowledge } \\
\text { Knowledge } \\
\text { Knowledge; experience } \\
\text { Knowledge industry }\end{array}$ & 5 \\
\hline Experience & & $\begin{array}{c}\text { Factory experience } \\
\text { Experienced contractor } \\
\text { Knowledge experience } \\
\text { Experienced technicians on site } \\
\text { Experience }\end{array}$ & \\
\hline \multirow{5}{*}{ Management skills } & Cost management & Cost management & 1 \\
\hline & $\begin{array}{l}\text { Interpersonal and } \\
\text { integrated skills }\end{array}$ & $\begin{array}{c}\text { Integrated skills } \\
\text { Interpersonal skills } \\
\text { Integrated management skills } \\
\text { Understanding of collaborative working }\end{array}$ & 4 \\
\hline & Operational skills & $\begin{array}{l}\text { Operational } \\
\text { Operational skills } \\
\text { Operation skills } \\
\text { Operational skills }\end{array}$ & 4 \\
\hline & Planning & $\begin{array}{l}\text { Management skills } \\
\text { Planning skills } \\
\text { Strategic planning } \\
\text { Planning } \\
\text { Management skills } \\
\text { Management skills }\end{array}$ & 6 \\
\hline & Production management & $\begin{array}{l}\text { Production management resource } \\
\text { Professional supply chain management } \\
\text { Supply chain management skills }\end{array}$ & 3 \\
\hline
\end{tabular}


Table 5. Cont.

\begin{tabular}{|c|c|c|c|}
\hline Themes & Sub-Themes & Illustrative Responses & Tally \\
\hline $\begin{array}{c}\text { Practical and } \\
\text { vocational skills }\end{array}$ & & $\begin{array}{c}\text { Practical skills } \\
\text { Factory experience } \\
\text { Filter/pre-assembly skills } \\
\text { Carpentry } \\
\text { Vocational skills } \\
\text { Practical skills } \\
\text { Carpentry, plumbing, electrical } \\
\text { Carpentry, plumbing }\end{array}$ & 8 \\
\hline $\begin{array}{l}\text { Research and } \\
\text { development }\end{array}$ & & $\begin{array}{c}\text { R\&D } \\
\text { Government support in Research and Development } \\
\text { Product development } \\
\text { Advocacy research and marketing }\end{array}$ & 4 \\
\hline Training & & $\begin{array}{c}\text { R\&D } \\
\text { Government support in Research and Development } \\
\text { Product development } \\
\text { Advocacy research and marketing }\end{array}$ & 4 \\
\hline
\end{tabular}

\subsubsection{Ways to Improve Skill Shortage in Prefabrication Supply Chain}

To seek improvement to the skill shortage issues within the prefabrication sector, participants were asked to suggest measures that could be taken to increase prefabrication in the NZ residential construction sector. Similar to the total responses for critical skills, 36 of the 49 participants answered this question. After coding the responses, the following themes were found: collaboration, designs and prototypes, government support, infrastructure changes, labour costs, legislation and regulations, marketing and public awareness, material resources, projects outside major cities, technology, time, and training. Table 6 presents the themes, sub-themes, illustrative response and the total in each category. Government support and marketing and public awareness were the dominant themes (13 and 10, respectively), followed by legislation and regulations. Through the questionnaire survey, the research contributors have enriched the content of this research with their useful responses on how to ease the current constraints preventing the broader uptake of prefabrication in the NZ residential construction industry.

Table 6. Essential measures to increase prefabrication.

\begin{tabular}{|c|c|c|c|}
\hline Themes & Sub-Themes & Illustrative Responses & Tally \\
\hline Collaboration & & $\begin{array}{c}\text { Effective collaborate with clients and manufacturers } \\
\text { Improve interface and connection between builders and prefab } \\
\text { companies } \\
\text { Engagement with stakeholders } \\
\text { Establishing more production facilities to deliver fabricated } \\
\text { buildings }\end{array}$ & 4 \\
\hline $\begin{array}{l}\text { Design and } \\
\text { prototypes }\end{array}$ & & $\begin{array}{c}\text { Quality } \\
\text { Easy instalment, less complexity } \\
\text { Design orientation towards mass production } \\
\text { Flexible modules } \\
\text { Repeat designs } \\
\text { Built prototypes to explain/experience prefabrication }\end{array}$ & 6 \\
\hline
\end{tabular}


Table 6. Cont.

\begin{tabular}{|c|c|c|c|}
\hline Themes & Sub-Themes & Illustrative Responses & Tally \\
\hline \multirow{3}{*}{$\begin{array}{l}\text { Government } \\
\text { support }\end{array}$} & Financial support & $\begin{array}{l}\text { Government financial support } \\
\text { Government financial support } \\
\text { Government support, financial incentive } \\
\text { Government support fund }\end{array}$ & 4 \\
\hline & Incentives & $\begin{array}{c}\text { Government proactive approach } \\
\text { Government support and incentives } \\
\text { Government support } \\
\text { Government support } \\
\text { Government support is highly required by introducing new and } \\
\text { subsidized projects } \\
\text { Government initiatives } \\
\text { Govt commitment to prefab } \\
\text { Govt support } \\
\text { Special government's incentives }\end{array}$ & 9 \\
\hline & $\begin{array}{l}\text { Regulations and } \\
\text { mandates }\end{array}$ & $\begin{array}{c}\text { Government regulation to prescribe minimum expectations in } \\
\text { prefabrication } \\
\text { Government mandate/leadership }\end{array}$ & 2 \\
\hline $\begin{array}{l}\text { Infrastructure } \\
\text { changes }\end{array}$ & & $\begin{array}{l}\text { Improve infrastructure } \\
\text { Improve NZ infrastructure }\end{array}$ & 2 \\
\hline Labour costs & & Reduce labour cost & 1 \\
\hline $\begin{array}{l}\text { Legislation and } \\
\text { regulations }\end{array}$ & & $\begin{array}{c}\text { Better BCA Acceptance } \\
\text { Flexible legislations } \\
\text { Legislative mandate } \\
\text { Streamline consenting process } \\
\text { Local authority coordination } \\
\text { Improve building consent process } \\
\text { Flexible regulations and legislations }\end{array}$ & 7 \\
\hline
\end{tabular}

Public awareness

Improve local knowledge in prefabrication manufacturing

More exposure to capabilities and solutions

Marketing

Marketing and

public awareness
Industry seminars

Increase the awareness of the prefabrication industry benefits.

Culture change towards prefabrication

Awareness and education about prefabrication

Academic institutions

Improved awareness creation

Education

Availability or supply chain

Easy procurement

Material resources

Reliable material resources

Establishing more production facilities to deliver prefabricated buildings

More project outside Auckland

More projects outside major cities

Better use of technology

Adapt new technologies

Using of innovative technology

Time consumption

Time

Construction time

Time saving by prefabricated construction

Less lead time 
Table 6. Cont.

\begin{tabular}{|c|c|c|c|}
\hline Themes & Sub-Themes & Illustrative Responses & Tally \\
\hline Training & & $\begin{array}{c}\text { Teaching architects } \\
\text { Training } \\
\text { Industry training for tradesman } \\
\text { Hire qualified labour } \\
\text { Train the building workers to be familiar with the industry } \\
\text { technology } \\
\text { Develop manufacturing capabilities }\end{array}$ & 6 \\
\hline
\end{tabular}

\subsubsection{Ways to Improve Skill Shortage in Prefabrication Supply Chain}

The last open-ended question was to suggest ways the skill shortage can be improved in prefabrication construction. This question required participants to suggest some improvement to address relevant skill shortages in the prefabrication supply chain. A total of $37(76 \%)$ participants out of the 49 responded to this question-three out of every four. The data once again was coded into different themes. The emerging themes were apprenticeships and internships, public awareness, government support, skill sourcing, prefabrication in education, and training. There were no emergent sub-themes. From Table 7, it is clear that the dominant theme from the responses is around training (about 60\%) of the relevant construction workforce. Skill sourcing was highly suggested to tackle the relevant skill shortages in prefabrication construction, followed by government support, apprenticeships and internships, prefabrication in education, and public awareness.

Table 7. Suggestions for improving the skill shortage issues in the prefabrication supply chain.

\begin{tabular}{|c|c|c|c|}
\hline Themes & Sub-Themes & Illustrative Responses & Tally \\
\hline $\begin{array}{l}\text { Apprenticeships } \\
\text { and internships }\end{array}$ & & $\begin{array}{c}\text { Taking on apprentices } \\
\text { Apprenticeship for different but specific trades } \\
\text { Apprenticeships } \\
\text { Internships }\end{array}$ & 5 \\
\hline Public awareness & & $\begin{array}{l}\text { Inspire more people to join } \\
\text { Need to spread knowledge about prefab } \\
\text { Awareness } \\
\text { Career information and qualifications }\end{array}$ & 4 \\
\hline $\begin{array}{l}\text { Government } \\
\text { support }\end{array}$ & & $\begin{array}{c}\text { Funding by government } \\
\text { Government funded programmes } \\
\text { Govt funded initiatives } \\
\text { Free training programmes supported by governments } \\
\text { Government incentives } \\
\text { Government programmes }\end{array}$ & 6 \\
\hline Skill sourcing & & $\begin{array}{c}\text { More Skilled Migrant Workers } \\
\text { Relax immigration rules for entry } \\
\text { Import offshore experienced skilled consultants } \\
\text { Immigration status for experienced tradespeople in the } \\
\text { prefabricated industry } \\
\text { Hire skilled labour from overseas } \\
\text { Adopting and accepting overseas skills and experiences } \\
\text { External sourcing of labour only contracts } \\
\text { Undertaking international joint ventures partnership with } \\
\text { well-established foreign organizations } \\
\text { Acquiring skills from overseas } \\
\text { Wider acceptance of overseas experience } \\
\text { Flexible and motivated immigration categories to attract foreign skills } \\
\text { Overseas skills }\end{array}$ & 12 \\
\hline
\end{tabular}


Table 7. Cont.

\begin{tabular}{|c|c|c|c|}
\hline Themes & Sub-Themes & Illustrative Responses & Tally \\
\hline $\begin{array}{l}\text { Prefabrication in } \\
\text { education }\end{array}$ & & $\begin{array}{c}\text { Prefabrication to be one course of civil engineering programme } \\
\text { Improve education system } \\
\text { Polytechnic education } \\
\text { Prefabrication technology to be part of civil engineering } \\
\text { Partner with educational facilities }\end{array}$ & 5 \\
\hline Training & & $\begin{array}{c}\text { Train more NZ Workers } \\
\text { Effective training sessions } \\
\text { Extensive workforce training } \\
\text { Training and re-training of personnel } \\
\text { Train more people for specific trades } \\
\text { Training local industry workers } \\
\text { broaden skills } \\
\text { Training }(\times 6) \\
\text { On the job training } \\
\text { Funded training by the government } \\
\text { Vocational training } \\
\text { Offer more training opportunities via tech and high school programs } \\
\text { Vocational training } \\
\text { Intensive vocational training } \\
\text { More specialized vocational training program } \\
\text { Training and upskilling of existing work force } \\
\text { Free training programmes supported by governments }\end{array}$ & 22 \\
\hline
\end{tabular}

\section{Discussion of Findings}

The results of this research imply that identifying specific skill issues in the prefabrication supply chain will significantly improve the adoption of prefabrication in the residential construction sector. This study set out to understand the critical skills required for the NZ prefabricated residential construction supply chain and suggest improvement measures from the standpoint of industry stakeholders. Both quantitative (close-ended) and qualitative (open-ended) data generated through an online questionnaire were combined and reviewed to answer the research question formulated. To enrich this section, the research findings will be synthesized with key literature review references. This will help understand the current research study within a NZ context. The following sections will discuss the results from the current study.

\subsection{Skill Issues}

To address the first research question, this study considered four possible issues in NZ's prefabricated construction industry. These included the difficulty of recruiting skilled workers, not hiring labourer with multiple skills, insufficient training placements available in the industry, and not borrowing overseas labour. Our study confirmed difficulty in recruiting skilled workers, not hiring multi-skilled labour, and not borrowing overseas labour are all significant issues in the prefabricated construction industry. This study support that of [38]. However, insufficient training placements available in the industry is not a prominent issue. This finding is consistent with the results from the open-ended questions. There are placement opportunities within prefabrication organizations; it is the trainees that are lacking. Nevertheless, there are current government initiatives that promote training placements within construction for people wanting to get into the industry. The skills issues found in this study are in line with some of those identified to be limiting the adoption of prefabrication. This confirms studies by Navaratnam et al. [32,35,40]. A close examination of the responses from the open-ended questions shows challenges with digital skills, and these were frequently mentioned. These include digital technologies skillsets such as DFMA, BIM, IT, CAD and automation. This finding is consistent with 
Miles and Whitehouse [55], Jennifer and Clare [56]. Therefore, the skills necessary for prefabrication construction are not readily available.

\subsection{Essential Measures and Suggestions for Improvement}

The five possible measures were investigated to increase prefabrication uptake in the NZ housing supply chain. The industry experts most often highlighted stakeholder collaborations and using technology for upfront planning in the residential prefabrication sector as possible measures. As implied by these results, technology-enabled collaborative planning with supply chain partners would be extremely useful for NZ construction companies to increase their adoption of prefabrication as a viable alternative in housing production. Some of the themes that emerged from the open-ended questions support the five measures presented to the participants. The participants indicated effective collaboration with clients and manufacturers, improving interface and connection between builders and prefab companies, and engagement with stakeholders as focus points. They also indicated that establishing more production facilities to deliver fabricated buildings was important for effective uptake of prefabrication. Some other measures noted by participants included the adaptation of new technologies, and the use of innovative technologies to improve the adoption of prefabrication. From these responses, it can be concluded that collaboration amongst all stakeholders is key to prefabrication in NZ.

There were references made to the role of government support to encourage adoption of prefabrication in New Zealand. Government support could take the form of financing and incentive schemes to prefabrication companies, taking a more proactive approach to matters relating to prefabrication, introducing new and subsidized project initiatives, and improving regulations and commitment to prefabrication. Our study produced results that corroborate a great deal of the previous work in this field [3]. In addition, marketing and public awareness were also highly indicated. Awareness can be created through marketing, industry workshops and seminars, dissemination of empirical research, and the promotion of cultural and practice changes within the construction industry. For the industry to improve the skill issues within its organizations, it is important to create public awareness of the benefits of prefabrication. These findings support previous research conclusions [31]. Our study also confirms that the training of architects and designers, and specialist trades in prefabrication, are critical to ensuring the required mindset for prefabrication. Similarly, Ginigaddar et al. [36] refers to extensive workforce training in professional and vocational skills. Participants have also indicated that management skills are equally important. Management skills such as cost management, interpersonal and integration skills, operations and logistics, planning and production management were all indicated as 'must haves' in prefabrication. Hence, we assert that curriculum reviews are sacrosanct at all levels of construction-related training. Apprenticeships and internship schemes will also encourage the growth of prefabrication trades within NZ. This is in line with McGinnis [32] on the cruciality of training for prefabrication.

Finally, the role of overseas labour was mentioned by the participants as a stop gap to addressing current skills shortages in the prefabrication industry. Participants suggested the recruitment of more skilled migrant workers (on and offshore), relaxing immigration rules for entry, and undertaking joint ventures partnerships with well-established foreign organizations could collectively improve the skillsets of the locally available workforce.

\section{Conclusions}

The present study was designed to determine the key skills required to facilitate the uptake of prefabrication and to suggest improvement measures in NZ. If skills issue in prefabrication are to be addressed successfully in NZ residential housing construction, certain skills identified in the current study would need to be developed. This study extends previous studies' results by providing information on the critical skills necessary for prefabrication to reach its full potential in the NZ construction industry. A major contribution to theory and practice is the insight provided into the skill requirement 
in prefabrication sector within the context of NZ construction industry. Participants in the study were industry stakeholders who offered their perspectives on improvement opportunities, too. The training of the construction workforce is significant. With reference to the concept of circular economy, an appropriately trained prefabrication workforce is in position to improve resource utilization and reduce wastes. Consequently, social economic and environmental benefits are likely to be achieved, not only for prefabricated residential construction, but for the whole of the construction sector.

Investment in training programmes is a prerogative of all stakeholders. More so, the NZ government can become the catalyst for educational institutions to deliver on relevant curricula and qualifications. Government support in the external sourcing of international skills was suggested to improve current skill shortages in the prefabrication sector. The research provides useful and structured information for classifying the prefabrication skills challenges; thus, the ultimate goals of improving the uptake of prefabrication is achievable. The NZ context is expounded in the study as it grapples with means through which full advantages of prefabrication can be realized.

We conclude that the shortages in management, digital architectural and design, and vocational skills as they relate to residential construction have to be improved as a matter of necessity. There is a need to expand the scope of this study to reach other sub-sectors of the prefabrication industry such as commercial, educational and airport buildings. The study showed the importance of using modern technologies to provide better upfront planning in the residential prefabrication sector. Nevertheless, further research on this will help prefabrication to lead the industry and enhance the future of design and architecture.

Finally, to improve the inferences from the study, certain limitations could provide the opportunity to conduct further research. This study was constrained to the volume of responses and the percentage of participants reluctant to discuss their thoughts about the industry and their business in general. Therefore, caution must be applied in generalizing the study results considering the limited sample size. Further, the ability to collect more information was limited by COVID-19 movement restrictions and lockdown. Therefore, a larger sample size covering other regions may be investigated in future studies through random sampling.

Author Contributions: Conceptualization, F.E.R. and D.A.S.S.; methodology, F.E.R., F.M.A. and C.S.; validation, F.E.R. and D.A.S.S.; formal analysis, F.E.R. and C.S.; investigation, F.M.A., F.E.R. and D.A.S.S.; data curation, F.M.A. and C.S.; writing-original draft preparation, F.M.A., F.E.R. and C.S.; writing—review and editing, F.E.R. and D.A.S.S.; visualization, F.E.R.; supervision, F.E.R. and D.A.S.S.; project administration, F.E.R.; funding acquisition, F.E.R. All authors have read and agreed to the published version of the manuscript.

Funding: This research was funded by the School of Future Environment, Auckland University of Technology, NZ.

Institutional Review Board Statement: The study was conducted in accordance with the Auckland University of Technology Human Ethics Guidelines, and approved by the Human Ethics Committee (AUTEC Reference Number 20/396, 16 December 2020).

Informed Consent Statement: Informed consent was obtained from all subjects involved in the study.

Data Availability Statement: The data presented in this study are available on request from the corresponding author.

Acknowledgments: The authors wish to acknowledge Zina Abu Ali for her contribution.

Conflicts of Interest: The authors declare no conflict of interest.

\section{References}

1. Razkenari, M.; Fenner, A.; Shojaei, A.; Hakim, H.; Kibert, C. Perceptions of offsite construction in the United States: An investigation of current practices. J. Build. Eng. 2020, 29, 101138. [CrossRef]

2. Chan, J.K.; Chan, A.P.; Kung, F.W. Using innovative prefabrications as the source of competitive advantage for contractors-Case studies in Hong Kong. Archit. Sci. Rev. 2004, 47, 183-192. [CrossRef] 
3. Rahimian, F.P.; Goulding, J.; Akintoye, A.; Kolo, S. Review of motivations, success factors, and barriers to the adoption of offsite manufacturing in Nigeria. Procedia Eng. 2017, 196, 512-519. [CrossRef]

4. Seike, T.; Kim, Y.; Hosaka, Y.; Ida, S.; Masuda, T. Intraregional reuse of emergency temporary housing in Japan. Sustain. Cities Soc. 2018, 42, 650-662. [CrossRef]

5. Scofield, R.; Wilkinson, S.; Potangaroa, R.; Rotimi, F. Driving Innovative Offsite Construction Techniques in New Zealand. In Proceedings of the Global Innovation in Construction Conference, Loughborough, UK, 13-16 September 2009.

6. Samarasinghe, D.A.S. The housing crisis in Australia and New Zealand: A comparative analysis through policy lenses. Int. J Constr. Supply Chain. Manag. 2021, 10, 212-223. [CrossRef]

7. Moradibistouni, M.; Vale, B.; Isaacs, N. Evaluating Sustainability of Prefabrication Methods in Comparison with Traditional Methods. In International Conference on Sustainability in Energy and Buildings; Springer: Cham, Switzerland, 2018 ; pp. $228-237$.

8. Ferdous, W.; Bai, Y.; Ngo, T.D.; Manalo, A.; Mendis, P. New advancements, challenges and opportunities of multi-storey modular buildings-A state-of-the-art review. Eng. Struct. 2019, 183, 883-893. [CrossRef]

9. Shahzad, W.; Mbachu, J.; Domingo, N. Marginal productivity gained through prefabrication: Case studies of building projects in Auckland. Buildings 2015, 5, 196-208. [CrossRef]

10. Moradibistouni, M.; Gjerde, M. Potential for Prefabrication to Enhance the New Zealand Construction Industry. In Proceedings of the Back to the Future: The Next 50 Year, Wellington, New Zealand, 29 November-2 December 2017; pp. 427-435. Available online: http://anzasca.net/wp-ontent/uploads/2017/11/ASA_2017_Moradibistouni_Gjerde.pdf (accessed on 8 September 2020).

11. Chen, C.; Tang, L.C.M.; Jin, Y. Development of 5D BIM-based Management System for Pre-Fabricated Construction in China. In Proceedings of the International Conference on Smart Infrastructure and Construction 2019 (ICSIC) Driving Data-Informed Decision-Making, Cambridge, UK, 8-10 July 2019; ICE Publishing: Scotland, UK, 2019; pp. 215-224.

12. Su, B.; Heshmati, A.; Geng, Y.; Yu, X. A review of the circular economy in China: Moving from rhetoric to implementation. J. Clean. Prod. 2013, 42, 215-227. [CrossRef]

13. Minunno, R.; O'Grady, T.; Morrison, G.M.; Gruner, R.L.; Colling, M. Strategies for applying the circular economy to prefabricated buildings. Buildings 2018, 8, 125. [CrossRef]

14. Van Stijn, A.; Gruis, V. Towards a circular built environment: An integral design tool for circular building components. Smart Sustain. Built Environ. 2020, 9, 635-653. [CrossRef]

15. Duncheva, T.; Hairstans, R. Decision support tool for enhancing the economic impact of construction using offsite systems. Modul. Offsite Constr. MOC Summit Proc. 2019, 116-123. [CrossRef]

16. Osobajo, O.A.; Oke, A.; Omotayo, T.; Obi, L.I. A systematic review of circular economy research in the construction industry. Smart Sustain. Built Environ. 2020. [CrossRef]

17. Tindale, A. Just How Big is the Housing Problem: New Zealand Planning Institute; New Zealand Planning Institute: Auckland, New Zealand, 2019.

18. Dale, M.C.; O’Brien, M.; John, S.S. Our Children, Our Choice: Priorities for Policy. Child Poverty Action Group. 2014. Available online: https: / / www.cpag.org.nz/assets/Publications/1410063-0\%20Our\%20Children\%20Our\%20Choice\%202014.pdf (accessed on 20 September 2020).

19. Johnson, A.; Howden, P.; Eaqub, C.S. A Stocktake of New Zealand's Housing. 2018. Available online: https:/ / www.beehive.govt. $\mathrm{nz} /$ sites/default/files/2018-02/A\%20Stocktake\%20Of\%20New\%20Zealand\%27s\%20Housing.pdf (accessed on 20 August 2020).

20. Kiwibank. New Zealand's Housing Shortage is Getting Worse, Not Better. Scoop Business. 2019. Available online: https: //www.scoop.co.nz/stories/BU1907/S00495/new-zealands-housing-shortage-is-getting-worse-not-better.htm (accessed on 15 October 2020).

21. REINZ. Residential Press Release for June 2021. The Real Estate Institute of New Zealand (REINZ). 2021. Available online: https:/ / www.reinz.co.nz/residential-June-2021 (accessed on 25 July 2020).

22. Edmund, S. NZ House Prices are Among the Most Unaffordable in the World: Survey. STUFF. 2019. Available online: https: //www.stuff.co.nz/business/110049950/auckland-ranked-among-worlds-least-affordable-cities-in-housing-report (accessed on 5 October 2020).

23. Kwan, S. Hong Kong Homes Remain World's Least Affordable for 10th Year. 2020. Available online: https://www.bloomberg. $\mathrm{com} /$ news/articles/2020-01-20/hong-kong-homes-remain-world-s-least-affordable-for-10th-year (accessed on 30 August 2020).

24. O'Connor, J.T.; O'Brien, W.J.; Choi, J.O. Critical success factors and enablers for optimum and maximum industrial modularization. J. Constr. Eng. Manag. 2014, 140, 04014012-1-11. [CrossRef]

25. Blismas, N.; Wakefield, R. Drivers, constraints and the future of offsite manufacture in Australia. Constr. Innov. 2009, 9, 72-83. [CrossRef]

26. Durdyev, S.; Ismail, S. Offsite manufacturing in the construction industry for productivity improvement. Eng. Manag. J. 2019, 31, 35-46. [CrossRef]

27. Arif, M.; Goulding, J.; Rahimian, F.P. Promoting off-site construction: Future challenges and opportunities. J. Archit. Eng. 2012, 18, 75-78. [CrossRef]

28. Burgess, J.C.; Buckett, N.R.; Page, I.C. Prefabrication Impacts in the New Zealand Construction Industry (SR 279 (2013)); BRANZ: Judgeford, New Zealand, 2013.

29. PBC Today. The Year Modular Construction goes Mainstream? Modular Construction News. 2020. Available online: https: / / www.pbctoday.co.uk/news/mmc-news/2020-modular-construction/70496/ (accessed on 20 July 2020). 
30. Arif, M.; Killian, P.; Goulding, J.; Wood, G.; Kaushik, A. Barriers and Challenges for Offsite Construction in UK Housing Sector; University of Salford: Salford, UK, 2017.

31. Lovell, H.; Smith, S.J. Agencement in housing markets: The case of the UK construction industry. Geoforum 2010, 41, 457-468. [CrossRef]

32. McGinnis, B. A 10-Year Change Programme Developing Offsite Construction Skills for the Challenges Ahead. UK Commission for Employment and Skills. 2015. Available online: https:/ /assets.publishing.service.gov.uk/government/uploads/system/ uploads/attachment_data/file/469805/151021_OSCS_brochure_for_web_reduced.pdf (accessed on 2 October 2020).

33. Minister for Industry, Science and Technology. Pre-Fab Innovation Lab for Building Industry. 2019. Available online: https: //www.minister.industry.gov.au/ministers/karenandrews/media-releases/pre-fab-innovation-lab-building-industry (accessed on 7 September 2020).

34. Hampson, K.; Brandon, P. Construction 2020: A Vision for Australia's Property and Construction Industry; CRC Construction Innovation: Boca Raton, FL, USA, 2004.

35. Navaratnam, S.; Ngo, T.; Gunawardena, T.; Henderson, D. Performance review of prefabricated building systems and future research in Australia. Buildings 2019, 9, 38. [CrossRef]

36. Ginigaddara, B.; Perera, S.; Feng, Y.; Rahnamayiezekavat, P. Offsite construction skills evolution: An Australian case study. Constr Innov. 2021, 22, 41-56. [CrossRef]

37. BCA. BCA Prefabricated Prefinished Volumetric Construction (PPVC). 2019. Available online: https://www.bca.gov.sg/ BuildableDesign/ppvc.html. (accessed on 11 November 2020).

38. Masood, R.; Lim, J.B.; González, V.A. Performance of the supply chains for New Zealand prefabricated house-building. Sustain Cities Soc. 2021, 64, 102537. [CrossRef]

39. Goulding, J.S.; Pour Rahimian, F.; Arif, M.; Sharp, M.D. New offsite production and business models in construction: Priorities for the future research agenda. Archit. Eng. Des. Manag. 2015, 11, 163-184. [CrossRef]

40. Wu, G.; Yang, R.; Li, L.; Bi, X.; Liu, B.; Li, S.; Zhou, S. Factors influencing the application of prefabricated construction in China: From perspectives of technology promotion and cleaner production. J. Clean. Prod. 2019, 219, 753-762. [CrossRef]

41. Construction Industry Council. This Ministerial Briefing Document Sets out the Views of the Construction Industry Council on a Range of Core Policy Matters Facing the Building and Construction Industry. 2012. Available online: http://nzcic.co.nz/wpcontent/uploads/2015/10/CIC-BIM-2012-FINAL.pdf (accessed on 8 August 2020).

42. Hunt, G. Valuing the Role of Construction in the New Zealand Economy. PWC. 2016. Available online: https://www.pwc.co.nz/ pdfs/CSG-PwC-Value-of-Construction-Sector-NZ.pdf (accessed on 15 August 2020).

43. PrefabNZ. Capacity and Capability Report. 2018. Available online: https://www.prefabnz.com/Images/Assets/9759/1 /PrefabNZ\%20CnC\%20Report\%20FINAL\%20rebranded\%20with\%20new\%20logo\%2020180920.pdf (accessed on 10 September 2020).

44. PrefabNZ. Prefb Roadmap: A Way forward for Prefabrication in New Zealand (2013-2018). 2014. Available online: https: / / prefabnz.wixsite.com/prefabnz-offsitenz (accessed on 5 September 2020).

45. Xue, H.; Zhang, S.; Su, Y.; Wu, Z. Factors affecting the capital cost of prefabrication-A case study of China. Sustainability 2017, 9, 1512. [CrossRef]

46. Kennerley, T. Planning Barriers for Prefabricated Housing (ER36). BRANZ. 2019. Available online: https://www.prefabnz. com/Downloads/Assets/14113/1/ER36\%20Planning\%20barriers\%20for\%20prefabricated\%20housing.pdf (accessed on 8 August 2020).

47. Mao, C.; Shen, Q.; Pan, W.; Ye, K. Major Barriers to Off-Site Construction: The Developer's Perspective in China. J. Manag. Eng. 2015, 31, 04014043. [CrossRef]

48. Bendi, D.; Rana, M.Q.; Arif, M.; Goulding, J.S.; Kaushik, A.K. Understanding Off-Site Readiness in Indian Construction Organisations. Constr. Innov. 2020, 21, 105-122. [CrossRef]

49. Armstrong, G. Climbing the Curve. KPMG International. 2015. Available online: https://assets.kpmg/content/dam/kpmg/ pdf/2015/05/construction-survey-201502.pdf (accessed on 12 August 2020).

50. The Construction and Property Services Industry Skills Council. Job Skills in Prefabricated Construction; International Specialised Skills Institute: Carlton, VIC, Australia, 2014.

51. Sooriyamudalige, N.; Domingo, N.; SHahzad, W.; Childerhouse, P. Barriers and enablers for supply chain integration in prefabricated elements manufacturing in New Zealand. Int. J. Constr. Supply Chain. Manag. 2020, 10, 73-91. [CrossRef]

52. Bell, P. Future of New Zealand's Prefab Industry. Architecture Now. 2011. Available online: https://architecturenow.co.nz/ articles/progressing-prefab / (accessed on 12 December 2020).

53. Chen, H.; Samarasinghe, D.A.S. The Factors Constraining the Adoption of Prefabrication in New Zealand Residential Construction Sector. In Proceedings of the New Zealand Built Environment Research Symposium (NZBERS), Auckland, New Zealand, 21 July 2011; Available online: https:/ / nzbers.massey.ac.nz/wpcontent/uploads/2020/03/Proceedings-NZBERSFeb2020.pdf (accessed on 15 November 2020).

54. Sahin, O.; Miller, D.; Mohamed, S. Value-based modelling: An Australian case of off-site manufactured buildings. Int. J. Constr. Manag. 2018, 18, 34-52. [CrossRef]

55. Miles, J.; Whitehouse, N. Offsite Housing Review; Construction Industry Council: London, UK, 2013. 
56. Jennifer, B.; Clare, V. Faster, Smarter, More Efficient: Building Skills for Offsite Construction; Construction Industry Training Board: London, UK, 2017.

57. Arashpour, M.; Wakefield, R.; Abbasi, B.; Lee, E.W.M.; Minas, J. Off-site construction optimization: Sequencing multiple job classes with time constraints. Autom. Constr. 2016, 71, 262-270. [CrossRef]

58. Gruszka, A. Digital foundations: How Technology is Transforming Australia's Construction Sectors; StartupAUS: Sydney, Australia, 2017.

59. Southern, J. Smart Construction-How offsite manufacturing can transform our industry; KPMG International: Amsterdam, The Netherlands, 2016.

60. Daly, G. Prefabricated Housing in Australia. Skill Deficiencies and Workplace Practice; International Specialised Skills Institute Incorporation: Victoria, Australia, 2009.

61. Frey, C.B.; Osborne, M.A. The future of employment: How susceptible are jobs to computerisation? Technol. Forecast. Soc. Chang. Vol. 2017, 114, 254-280. [CrossRef]

62. McLafferty, S.L. Conducting Questionnaire Surveys. In Key Methods in Geography, 2nd ed.; Sage: Thousand Oaks, CA, USA, 2010; pp. 77-88. Available online: https://is.muni.cz/el/sci/jaro2015/Z0132/um/54979481/_Nicholas_Clifford_Gill_Valentine_ _Key_Met-ods_in_BookFi.org_.pdf\#page=100 (accessed on 20 January 2021).

63. Regmi, P.R.; Waithaka, E.; Paudyal, A.; Simkhada, P.; Teijlingen, E.V. Guide to the design and application of online questionnaire surveys. Nepal J. Epidemiol. 2016, 6, 640-664. Available online: https://www.nepjol.info/index.php/NJE/issue/view/1190 (accessed on 15 December 2020). [CrossRef] [PubMed]

64. Qualtrics. Listening Is More Important Than Ever: Qualtrics Is Now Offering Its Survey Software for Free. 2020. Available online: https:/ / www.qualtrics.com/blog/qualtrics-survey-software-free/ (accessed on 20 November 2020).

65. Van Teijlingen, E.R.; Rennie, A.; Hundley, V.; Graham, W. The importance of conducting and reporting pilot studies: The example of the Scottish births survey. J. Adv. Nurs. 2001, 34, 289-295. [CrossRef] [PubMed]

66. Almughrabi, F.M.; Samarasinghe, D.A.S.; Rotimi, F.E. Analysis of Skill Shortages in Prefabricated Residential Construction: A Case for New Zealand. In Proceedings of the 37th Annual ARCOM Conference, Association of Researchers in Construction Management, Woodhouse, UK, 6-7 September 2021; Scott, L., Neilson, C.J., Eds.; pp. 481-490.

67. Moore, C.G.; Carter, R.E.; Nietert, P.J.; Stewart, P.W. Recommendations for planning pilot studies in clinical and translational research. Clin. Transl. Sci. 2011, 4, 332-337. [CrossRef]

68. Mertens, D.M. Ethics of Qualitative Data Collection. In The Sage Handbook of Qualitative Data Collection; Sage Publications Ltd.: Thousand Oaks, CA, USA, 2018; pp. 33-48. [CrossRef]

69. Blaxter, L.; Hughes, C.; Tight, M. How to Research; McGraw-Hill Education: New York, NY, USA, 2010.

70. Jackson, K.; Bezeley, P. Qualitative Data Analysis with NVivo; Sage: Thousand Oaks, CA, USA, 2007.

71. Gioia, D.A.; Corley, K.G.; Hamilton, A.L. Seeking qualitative rigor in inductive research. Organ. Res. Methods 2012, 16, 15-31. [CrossRef]

72. Graebner, M.E.; Martin, J.A.; Roundy, P.T. Qualitative data: Cooking without a recipe. Strateg. Organ. 2012, 10, 276-284. [CrossRef]

73. Attride-Stirling, J. Thematic networks: An analytic tool for qualitative research. Qual. Res. 2001, 1, 385-405. [CrossRef] 